\title{
DIMENSIONS AND ATTRIBUTES BUILDING CORPORATE REPUTATION OF RURAL BUSINESSES
}

\author{
Miglè Šontaitè-Petkevičienè \\ Vytautas Magnus University, Lithuania \\ migle.sontaite-petkeviciene@vdu.lt
}

\begin{abstract}
Given the intensive competition between rural businesses, building and managing good corporate reputation of rural businesses is gaining its popularity among business owners, marketers as well as among scholars. Building and managing good corporate reputation is considered to be one of the crucial goals for businesses that leads to successful competition in ever changing business world. The aim of this research is to determine dimensions and attributes for building good corporate reputation in the framework of rural businesses. To reach the aim, this paper adopts analysis and synthesis of scientific and practical literature in the field of corporate reputation management and, focus group discussion. 23 attributes of corporate reputation representing 7 corporate reputation dimensions were generated from scientific and practical literature. Generated attributes were provided for the evaluation and discussion during the focus group discussion to 7 representatives of rural businesses' stakeholder groups, namely: customer, employee, supplier, business owner, media, local community, and expert. Empirical research proved 7 rural businesses' corporate reputation dimensions: Products \& Services, Innovation, Workplace, Governance, Citizenship, Leadership and Performance, each of the dimensions constituting of 3-4 corporate reputation attributes. For the further research, quantitative research to test corporate reputation dimensions and attributes and calculate its weights in the context rural businesses is necessary.
\end{abstract}

Key words: corporate reputation, corporate reputation dimensions, corporate reputation attributes, reputation formation, reputation management, rural.

\section{Introduction}

The construct of corporate reputation has gained a wide interest from theory as well as practice. The formation and management of good corporate reputation have become one of the most important tendencies in the management of organizations. Now in addition, rural businesses are coming to realize that they have much to learn in this area and that corporate reputation as a management technique is particularly appealing in the rural sector. Since corporate reputation formation and management of the rural businesses is quite a new topic, this sector lacks knowledge and tools how to build and manage good corporate reputation. Consequently, the question is not whether rural businesses should apply corporate reputation management but how, as certain corporate reputation management tools might not apply to rural businesses.

This paper focuses on dimensions and attributes of building and managing good corporate reputation in the context of rural businesses. The purpose of this research is to answer the question how to build and manage good corporate reputation of rural businesses.

The object of the research is corporate reputation formation and management in the context of rural businesses.

The aim of this research is to determine dimensions and attributes for building good corporate reputation in the framework of rural businesses.

The objectives of the paper are as follows: to analyze theoretical conceptualization of corporate reputation, its formation and management; to identify dimensions and attributes for building and managing good corporate reputation; to determine corporate reputation dimensions and attributes of rural businesses using focus group discussion method.

The paper consists of both theoretical and empirical analysis. The research methods used in the article include logical analysis, generalization and interpretation of scientific and practical literature. After the presentation of theoretical insights, research methodology is outlined, following with research findings. Finally, conclusions are stated.

The introduction of corporate reputation concept dates back to 1997 with the foundation of Reputation Institute (RI) and scholarly journal Corporate Reputation Review devoted solely to the topic. The founders of the institute and the journal, Charles J. Fombrun and Cees B.M. van Riel, are considered the key and most influential scholars in this topic. Since the establishment of RI and the first issue of the journal there is a great intensification of articles devoted entirely to the concept of corporate reputation.

Despite the broad interest among academics and practitioners in corporate reputation, there is a big confusion in the topic. Until now scholars and practitioners still argue on the definition of corporate reputation and the main components included in corporate reputation formation and management. Burke, Dowling, Wei (2018) believe that due to the fact that corporate reputation concept has been studied from various academic disciplines and stakeholder perspectives, there are many definitions in use. Pires, Trez (2018) agree that corporate reputation embraces a complex concept, with a diversity of definitions in the literature and this variety of concepts makes it 
difficult to adopt one definition and one method to measure the construct.

Dowling (2016) defines corporate reputation as an individual's overall evaluation of a company. Caruana, Cohen, Krentler (2006) suggest that corporate reputation is similar to an attitude and is based on the company's key attributes, performance and behavior. Fong (2013) states that corporate reputation can be defined as the assessment of the firm's ability to create value and to meet consumer expectations in relation to given attributes. Similarly, Walsh, Beatty (2007) defines corporate reputation as customers' overall evaluation of the firm, according to their reactions to the firm's offerings and communications, as well as their interactions with it. Barnett, Leih (2018) suggest that corporate reputation at any point in time is understood and measured as an average, perhaps weighted, of what various constituencies think of the firm.

Scientific and practical literature provides a broad range of positive outcomes that good corporate reputation generates for organizations. Burke, Dowling, Wei (2018) believe that good corporate reputation acts as a signal of quality and a performance bond to internal stakeholders such as employees and external stakeholders such as customers. Because companies are expected to live up to their reputations, they generally endeavour to maintain or enhance stakeholder evaluations. Rindova, Martins (2012) supplement that from a strategic perspective, corporate reputation, has many of the attributes of an intangible asset because it is difficult for rivals to imitate, acquire or substitute, and can offer opportunities to gain a competitive advantage. It is possible to state that rural businesses having good corporate reputation might expect better organization performance, higher prices of products, higher customer attraction, bigger profits, higher market value, organizational appeal, customer/ employee satisfaction and many other important benefits.

In the academic literature, there is a number of contributions devoted to how organizations should build and manage their corporate reputation (e.g. Wiedmann $\&$ Buxel, 2005). The most commonly accepted view to the management of corporate reputation is that corporate reputation is created and managed by the actions undertaken within corporate identity and transmitted through corporate communications. It creates an image in the stakeholders' mind and in a longer perspective - a reputation (Gray \& Balmer, 1998; Rindova, 1997). Gray, Balmer (1998) indicate that a favourable corporate reputation requires more than just effective communication effort; it requires a meritorious identity that can only be moulded through consistent performance, usually over many years. A coordinated communication programme can, however, reinforce and promote a positive reputation.
Building and managing good corporate reputation of rural businesses is of big importance as well because as Burke, Dowling, Wei (2018) argues a good (or poor) corporate reputation can enhance (decrease) the likelihood that a particular product will be chosen over competing products. According to authors, the primary mechanism by which this can happen is a halo effect whereby the overall evaluation of the company influences evaluations of the product's features in a way that is consistent with this overall evaluation. Arslanagic-Kalajdzic, Zabkar (2017) and Helm (2013) argue that good corporate reputation may increase customers' value perceptions because good corporate reputation represents a quality signal that reduces customers' search costs as well as the resources (time, effort, money) needed to supervise the relationship and ensure that organization does not engage in opportunistic behavior.

However, Cintamür, Yüksel (2018) prove that since corporate reputation is an issue and a stakeholder-specific phenomenon, different stakeholder groups may have different evaluations of corporate reputation and each stakeholder group's reputation may have different dimensions. Therefore, according to the authors it is possible to argue that dimensions of corporate reputation might vary among different industries and stakeholder groups and so should be measured in terms of a single industry and stakeholder group. It means that not only they believe that the dimensions and attributions of corporate reputation might vary from one industry to another, but it might also vary among stakeholder groups as well. That is why it is possible to state that corporate reputation should be treated in terms of specific industries meaning corporate reputation of rural businesses might demonstrate specifics compared to other industries.

\section{Materials and Methods}

To achieve the aim of the paper this research adopts analysis and synthesis of scientific and practical literature in the field of corporate reputation management. In order to determine dimensions and attributes for building good corporate reputation, general scientific research methods were applied as well - systematic analysis, evaluation, generalization, comparison and abstraction. To identify dimensions and attributes of good corporate reputation for rural businesses, qualitative research method - focus group discussion - was applied.

Focus group discussion was organized with heterogenous participants. Representatives of 7 different stakeholder groups were invited to participate in the focus group discussion. Focus group discussion involved one representative from each rural businesses' stakeholder groups: one customer, 
one employee, one supplier, one business owner, one media representative, one local community member, and one expert in the field. Data from focus group discussion were analysed in a generalized mode, without taking into account neither represented stakeholder group nor demographic data.

A questionnaire was prepared for the focus group discussion. The questionnaire consisted of 23 closed questions provided in a form of statement. Before distributing the questionnaire, participants of focus group discussion were introduced with the aim of the discussion, its logic and expected result. Participants were also introduced with the rules of the discussion and were asked to introduce themselves to each other. The aim of the focus group discussion was to identify dimensions and attributes for building and managing good corporate reputation of rural businesses. Focus group discussion with the elements of semi-structured interviews was organized in February, 2019. The duration of focus group discussion was $1 \mathrm{~h} 30 \mathrm{~min}$.

Participants of focus group were asked to evaluate each closed question-statement using the Likert scale. Likert scale consisted of 5 meanings, were 5 had a meaning of absolutely agree, 4 - agree, 3 - neither agree, nor disagree, 2 - disagree, 1 - absolutely disagree. Questions-statements representing attributes of corporate reputation were provided for the evaluation by structuring them according to the dimensions of corporate reputation. While filling in the questionnaire participants of focus group were allowed to ask questions to the moderator of focus group. This allowed collecting reliable data as participants were provided with the clear meaning of the statements provided in the questionnaire. After filling in the questionnaire, members of focus group discussion were also asked to provide their insights on every dimension and attribute of corporate reputation provided in the questionnaire.

Based on the participants' answers average meanings of each corporate reputation attribute were calculated. Such calculation of data resulted that those attributes that were as close as possible to the average meaning of 5 would be considered as very important corporate reputation attribute for building corporate reputation of rural businesses. Average meanings between 3.5-4.4 were considered as important attributes for building good corporate reputation of rural businesses. And average meanings between 2.53.4 were considered as having average importance. Lower average meanings were not identified during this research proving the reliability of the RepTrak tool that was used as a basis for this research.

The logic of this research was constructed based on the logic of testing validity of Reputation Quotient (Gardberg, 2006; Groenland, 2002) and corporate reputation measurement method constructed by Helm
(2005). Since worldwide acknowledged corporate reputation management and measurement tools of RepTrak and Reputation Quotient were constructed using such logic, this research considers the selected method of research to provide reliable results. Research results collected during the focus group discussion with representatives of different stakeholder groups of rural businesses allows to identify what dimensions and attributes are used for building good corporate reputation of rural businesses.

\section{Results and Discussion}

In the scientific and practical literature most widely accepted views towards management and measurement of corporate reputation are based on social expectations. It is considered that social expectations reflect expectations of stakeholder groups towards the behavior of an organization and this describes its corporate reputation. In the last decade RepTrak became the most widely acknowledged and most widely used tool for the measurement and management of corporate reputation.

RepTrak tool was created by Reputation institute in 2006 and can be used for the measurement and management of corporate reputation. Van Riel, Fombrun (2008) indicates that RepTrak method is the first standardized and complex method that can be used at the international level for opinion measurement of various stakeholder groups. Vivader-Cohen (2007) states that RepTrak method is also used by the magazine 'Forbes' for annual World's most reputable companies rankings. RepTrak method is created in order to provide organizations with standardized framework for the identification of dimensions and attributes based on which corporate reputation is formed and managed (Reputation Institute, 2009).

RepTrak tool distinguishes 23 attributes grouped to 7 dimensions that are substantiated as valid criteria for the determination of stakeholder groups' support to the organization (Reputation Institute, 2009; Reputation Institute, 2018; Reputation Institute, 2019).

Exclusive attention in the RepTrak tool is given to 'RepTrak Pulse' tool that reflects the emotional connection of stakeholder groups towards an organization. 'RepTrak Pulse' tool provides 4 dimensions - Esteem, Admire, Trust and Feeling that determine emotions of stakeholder groups and allow getting insights on the emotional attitude of stakeholder groups towards an organization. This can be considered as the emotional aspects of corporate reputation. This is justified by the fact that Reputation Institute (2019) defines it as the FEEL aspect of corporate reputation.

Scientists and practitioners from Reputation Institute that created RepTrak tool believe that corporate reputation can be managed through the 
management of 7 very important dimensions of an organization. These 7 dimensions are internationally tested and proved to be the main aspects for building good corporate reputation. As Reputation Institute (2019) states, these 7 dimensions of RepTrak tool represent cognitive representation of stakeholder groups towards organizations. Reputation Institute (2019) defines it as the THINK aspect of corporate reputation.

A fundamental advantage of RepTrak tool is considered the fact that corporate reputation dimensions (van Riel, Fombrun, 2008) and indicators that constitute them (Reputation Institute, 2009) statistically do not depend on each other. Another key advantage of RepTrak tool is that all corporate reputation measurements are comparable between operating fields, countries and in time (Reputation Institute, 2009). As Reputation Institute (2019) indicates they measure 7600 companies per year, across 50 countries and $20+$ different industries. They help organizations answer three key questions: (1) What is my reputation and how does it compare?; (2) How can I improve and protect my reputation?; (3) What is the business impact of better managing my reputation?

While RepTrak tool has been used internationally across 50 countries and in $20+$ different industries this tool can be definitely considered as the most standardized tool for the management and measurement of corporate reputation of the companies from different industries. This leads to the logical assumptions that RepTrak tool might be the right and useful tool while building and managing good corporate reputation of rural businesses.

Cognitive consideration of various stakeholder groups in a form of perceptions and attitude is constructed towards 7 corporate reputation dimensions: Products \& Services, Innovation, Workplace, Governance, Citizenship, Leadership and Performance. Each corporate reputation dimension constitutes of 3-4 attributes. Reputation Institute (2019), Van Riel, Fombrun (2008) and others grouped 23 attributes of corporate reputation around
7 dimensions that can be considered as the main aspects of corporate reputation management at organizations from any industry, including - rural. For this reason, author of this paper believes that below listed 7 corporate reputation dimensions and 23 corporate reputation attributes might be the right dimensions and attributes for building and managing good corporate reputation of rural businesses:

1. Products/ services: High quality; Good value; Stands behind, Meets needs.

2. Innovation: Innovative; First to market; Adopts quickly.

3. Workplace: Rewards fairly; Equal opportunity; Employee concern.

4. Governance: Fair in business; Behaves ethically; Open and transparent.

5. Citizenship: Societal influence; Supports causes; Protects environment.

6. Leadership: Well-organized; Strong leader; Excellent management; Clear vision.

7. Performance: Growth prospects; Profitable company; Financial results.

According to Reputation Institute (2019) perceptions of all 23 corporate reputation attributes grouped to 7 dimensions provide main corporate reputation outcomes that can be defined as behavioural intentions. It means that by building good corporate reputation based on the 23 corporate reputation attributes grouped to 7 dimensions companies, including rural businesses, can expect the following corporate reputation outcomes from their stakeholder groups: Purchase; Advocate for; Accept; Defend, Work for, Invest in. Reputation Institute (2019) determines the main KPIs for tracking the abovementioned corporate reputation outcomes: Track of Sales, Loyalty, Profitability, Licence to operate and, Market value.

Researches conducted by Reputation Institute in the last 3 years (Reputation Institute, 2017; 2018; 2019) distinguishes the main global drivers of corporate reputation (Table 1).

Table 1

\section{Drivers of corporate reputation}

\begin{tabular}{|l|c|c|c|}
\hline & 2019 & 2018 & 2017 \\
\hline Products/ Services & $24.4 \%$ & $21.6 \%$ & $20.5 \%$ \\
\hline Innovation & $11.4 \%$ & $13.1 \%$ & $13.1 \%$ \\
\hline Workplace & $9.7 \%$ & $10.8 \%$ & $11.6 \%$ \\
\hline Governance & $15.7 \%$ & $15.0 \%$ & $15.0 \%$ \\
\hline Citizenship & $13.9 \%$ & $14.1 \%$ & $14.4 \%$ \\
\hline Leadership & $12.8 \%$ & $12.5 \%$ & $12.5 \%$ \\
\hline Performance & $12.1 \%$ & $12.9 \%$ & $12.9 \%$ \\
\hline
\end{tabular}

Source: derived by author from Reputation Institute (2017, 2018, 2019). 
Reputation Institute (2019) proves that delivering on the dimensions of good Governance and Citizenship and, Products/ Services is highly important while striving to build good corporate reputation. Data from researches conducted by Reputation Institute in the last 3 years (Reputation Institute, 2017; 2018; 2019) shows that the main driver of corporate reputation is Products/ Services with the weight of $24.4 \%$ and its importance for building good corporate reputation is growing significantly each year.

Another very important driver of good corporate reputation that organizations must focus on is Governance described by such attributes as: Fair in business; Behaves ethically; Open and transparent. This dimension of corporate reputation constitutes $15.7 \%$ of overall reputation of an organization and its importance for building good corporate reputation has been also growing during the recent years. Citizenship described by such attributes as Societal influence; Supports causes; Protects environment is the third most important dimension for building good corporate reputation. Its importance is slightly decreasing in recent years and constitutes $13.9 \%$ of the total reputation in 2019.

Less important dimensions for building good corporate reputation would be Workplace $(9.7 \%)$, Innovation (11.4\%), Performance (12.1\%) and Leadership (12.8\%). Workplace described by such attributes as: Rewards fairly; Equal opportunity; Employee concern, is the least important dimension for building good corporate reputation between various stakeholder groups. However, when taking into account attitude of the employees', the position of this dimension would move from the bottom to the top.

Reputation Institute (2019) argues that corporate reputation dimensions can be divided into enterprise dimensions and product related dimensions. Dimensions of Products/ Services and Innovation are considered as Product related dimensions. The rest of RepTrak dimensions (Performance, Leadership, Citizenship and Governance) are considered as Enterprise dimensions. Research made by Reputation Institute (2019) shows that enterprise dimensions are of growing importance - while importance of product related dimensions is declining. In 2019, perceptions of enterprise - who you are - drives two thirds of corporate reputation vs. what you sell which accounts for only one third. However, when company is selecting dimensions and attributes for corporate reputation management dimension of Products/ Services would be considered as the most important for its stakeholder groups.

Since the aim of this paper is to distinguish dimensions and attributes that build good corporate reputation of rural businesses, the focus group discussion with the main stakeholder groups of rural companies has been organized. The focus group discussion with 7 participants representing different stakeholder groups has been carried out in order to evaluate which corporate reputation dimensions and attributes from the RepTrak tool are important while building good corporate reputation of rural businesses. Participants of focus group with the use of questionnaire were asked to evaluate the importance of each corporate reputation attribute for building good corporate reputation of rural business from the point of view of the representing stakeholder group: a customer, employee, supplier, owner, media, local community, expert. Participants of focus group were asked to evaluate the importance of 23 corporate reputation attributes grouped by 7 dimensions. After the evaluation each attribute and dimension of corporate reputation was discussed with participants of focus group by asking them to provide their opinion on why they think each corporate reputation attribute is important while building corporate reputation of rural businesses from their point of view of a represented stakeholder group.

Statements representing each corporate reputation attribute that were provided for the evaluation during the focus group discussion are listed in Table 2. This table also summarizes the results from focus group discussion providing main conclusions and evaluations from representatives of rural businesses' stakeholder groups. Results provided in Table 2 shows the average meanings of each evaluated attribute from the filled in questionnaires and commonly agreed evaluation from all 7 focus group participants.

Results from focus group discussion prove that dimensions and attributes distinguished in RepTrak tool provide a basis for building and managing good corporate reputation of rural businesses. Participants of focus group representing 7 distinct stakeholder groups agreed that all attributes provided for evaluation are very important and important aspects while forming their attitude towards rural business. Attributes evaluated as most important attributes of rural businesses' corporate reputation constitute the same three dimensions of Products/ Services, Governance and Citizenship that researches by Reputation Institute proved as main drivers of corporate reputation globally.

Research proves that the most important attributes that build corporate reputation of rural businesses are High quality and Meets needs, each having the average of 4.9 points and representing the Products/ services dimension. Other attributes - Good value (Products/ services dimension), Open and transparent (Governance dimension) with the average of 4.8 points were evaluated as very important attributes while building and managing corporate reputation of rural businesses as well. Attributes like Fair in 
Dimensions and attributes that build corporate reputation of rural businesses

Table 2

\begin{tabular}{|c|c|c|c|}
\hline Dimensions & Attributes & & Importance \\
\hline \multirow{4}{*}{$\begin{array}{l}\text { Products/ } \\
\text { services }\end{array}$} & This organization offers high quality products and services & 4.9 & Very important \\
\hline & This organization offers value for money in products and services & 4.8 & Very important \\
\hline & This organization stands behind its products and services & 4.6 & Very important \\
\hline & Products and services of this organization meets customer needs & 4.9 & Very important \\
\hline \multirow{3}{*}{ Innovation } & This organization is innovative & 4.6 & Very important \\
\hline & This organization is first to market & 3.3 & Average importance \\
\hline & This organization adapts quickly to change & 3.8 & Important \\
\hline \multirow{3}{*}{ Workplace } & This organization rewards its employees fairly & 4.6 & Very important \\
\hline & This organization is concerned with its employees & 3.7 & Important \\
\hline & This organization offers equal opportunities to its employees & 3.2 & Average importance \\
\hline \multirow{3}{*}{ Governance } & This organization is open and transparent & 4.8 & Very important \\
\hline & This organization behaves ethically & 4.5 & Very important \\
\hline & This organization is fair in the way it does business & 4.7 & Very important \\
\hline \multirow{3}{*}{ Citizenship } & This organization supports good causes & 4.7 & Very important \\
\hline & This organization is environmentally responsible & 4.7 & Very important \\
\hline & This organization has positive influence on society & 4.1 & Important \\
\hline \multirow{4}{*}{ Leadership } & This organization has strong and appealing leader & 4.2 & Important \\
\hline & This organization has clear vision for it future & 3.1 & Average importance \\
\hline & This organization has excellent management & 4.3 & Important \\
\hline & This organization is well-organized & 4.7 & Very important \\
\hline \multirow{3}{*}{ Performance } & This organization performs better than expected & 4.1 & Important \\
\hline & This organization is profitable & 4.3 & Important \\
\hline & This organization has strong prospects for growth & 4.6 & Very important \\
\hline
\end{tabular}

business (Governance dimension), Supports causes (Citizenship dimension), Protects environment (Citizenship) and Well-organized (Leadership dimension are also considered as very important attributes of rural businesses' corporate reputation with an average of 4.7 points.

Attributes that participants of focus group considered as of average importance are Clear vision (Leadership dimension) with the average of 3.1 points, Equal opportunity (Workplace dimension) with the average of 3.2 points and First to market (Innovation dimension) with the average of 3.3 points.

Results from the focus group discussion generate the need for further research on corporate reputation management in the rural context. Deeper quantitative analysis of different stakeholder groups opinion helping to determine the weights of rural businesses' corporate reputation attributes and dimensions would help to provide a better tool for building and managing corporate reputation of rural businesses.

\section{Conclusions}

Based on the analysis of scientific and practical literature it is possible to conclude that there are many definitions of corporate reputation in use. However, many authors define corporate reputation as a perception and/ or attitudinal construct.

Scientific and practical literature provides a broad range of positive outcomes that good corporate reputation generates for organizations. Hence, good corporate reputation creates trust between different stakeholder groups and can be considered as a strong competitive advantage.

During the research it was distinguished that it is important to build and manage good corporate reputation of rural businesses. However, dimensions and attributes of rural businesses' corporate reputation might demonstrate specifics compared to other industries. The focus group discussion with representatives from different stakeholder groups of rural businesses prove that the most important attributes that build corporate reputation of rural businesses are High quality and Meets needs linked to the Products/ Services dimension. Other attributes Good value (Products/ Services dimension), Open and transparent (Governance dimension), Fair in business (Governance dimension), Supports causes (Citizenship dimension), Protects environment 
(Citizenship) and Well-organized (Leadership dimension) should be considered as very important attributes while building and managing corporate reputation of rural businesses as well. Even though, attributes - Clear vision (Leadership dimension),
Equal opportunity (Workplace dimension) and First to market (Innovation dimension) were considered as of average importance, rural businesses should not exclude them when building and managing good corporate reputation.

\section{References}

1. Arslanagic-Kalajdzic, M., \& Zabkar, V. (2017). Hold me responsible: the role of corporate social responsibility and corporate reputation for client-perceived value. Corporate Communications, 22(2), 209-219. DOI: 10.1108/CCIJ-01-2016-0012.

2. Barnett, M.L., \& Leih, S. (2018). Sorry to (not) burst your bubble: the influence of reputation rankings on perceptions of firms. Business \& Society. 57(5), 962-978. DOI: 10.1177/0007650316643919.

3. Burke, P.F., Dowling, G., \& Wei, E. (2018). The relative impact of corporate reputation on consumer choice: beyond a halo effect. Journal of Marketing Management. 34(13-14), 1227-1257. DOI: 10.1080/0267257X.2018.1546765.

4. Caruana, A., Cohen, C., \& Krentler, K.A. (2006). Corporate reputation and shareholders' intentions: an attitudinal perspective. Journal of Brand Management. 13(6), 429-440. DOI: 10.1057/palgrave. bm. 2540284.

5. Cintamür, I.G., \& Yüksel, C.A. (2018). Measuring customer based corporate reputation in banking industry: developing and validating an alternative scale. International Journal of Bank Marketing. 36 (7), 1414-1436. DOI: 10.1108/IJBM-11-2017-0227.

6. Dowling, G.R. (2016). Defining and measuring corporate reputations. European Management Review. 13(3), 207-223. DOI: 10.1111/emre.12081.

7. Fong, C.M., Lee, C.L., \& Du, Y. (2013). Target reputation transferability, consumer animosity, and crossborder acquisition success: a comparison between China and Taiwan. International Business Review. 22(1), 174-186. DOI: 10.1016/j.ibusrev.2012.03.004.

8. Gardberg, N.A. (2006). Reputatie, Reputation, Réputation, Reputazione, Ruf: A Cross-Cultural Qualitative Analysis of Construct and Instrument Equivalence. Corporate Reputation Review. 9(1), 39-61. DOI: 10.1057/palgrave.crr.1550009.

9. Gray, E.R., \& Balmer, J.M.T. (1998). Managing corporate image and corporate reputation. Long Range Planning. 31(5), 695-702. DOI: 10.1016.S0024-6301(98)00074-0.

10. Groenland, E.A.G. (2002). Qualitative Research to Validate the RQ Dimensions. Corporate Reputation Review. 4(4), 308-315. DOI: 10.1057/palgrave.crr.1540152.

11. Helm, S. (2005). Designing a Formative Measure for Corporate Reputation. Corporate Reputation Review. 8(2), 95-109. DOI: 10.1057/palgrave.crr.1540242.

12. Helm, S. (2013). How corporate reputation affects customers' reactions to price increases. Journal of Revenue and Pricing Management. 12(5), 402-415. DOI: 10.1057/rpm.2013.12.

13. Pires, V., \& Trez, G. (2018). Corporate reputation: a discussion on construct definition and measurement and its relation to performance. Revista de Gestão. 25(1), 47-64. DOI: 10.1108/REGE-11-2017-005.

14. Reputation Institute. (2009). Reputation Results of the Largest Companies in the Netherlands 2009. Retrieved March 10, 2019, from http://www.reputationinstitute.com/events/Reputation_Institute_ Netherlands_Results_2009.pdf.

15. Reputation Institute. (2017). 2017 Global RepTrak 100. The World's Most Reputable Companies. Retrieved March 10, 2019, from https://www.reputationinstitute.com/research/2017-global-reptrak.

16. Reputation Institute. (2018). Powering the world's most reputable companies. Retrieved March 10, 2019 , from https://www.reputationinstitute.com/research/2018-global-reptrak.

17. Reputation Institute. (2019). Winning in the New Reputation Economy. Retrieved March 10, 2019, from https://www.reputationinstitute.com/research/global-reptrak-2019-data-and-insights.

18. Rindova, V.P. (1997). The image cascade and the formation of corporate reputations. Corporate Reputation Review. 1(1-2), 188-194. DOI: 10.1057/palgrave.crr.1540042.

19. Rindova, V.P., \& Martins, L.L. (2012). Show me the money: a multidimensional perspective on reputation as an intangible asset. In M.L. Barnett \& T.G. Pollock (Eds.), The Oxford handbook of corporate reputations (pp. 16-33). Oxford: Oxford University Press.

20. Van Riel, C.B.M., \& Fombrun, C.J. (2008). Essentials of Corporate Communication: Implementing Practices for Effective Reputation Management. New York: Routledge. 
21. Vivader-Cohen, D. (2007). Reputation Beyond the Rankings: A Conceptual Framework for Business School Research. Corporate Reputation Review, 10(4). DOI: 10.1057/palgrave.crr.1550055.

22. Walsh, G., \& Beatty, S.E. (2007). Customer-based corporate reputation of a service firm: scale development and validation. Journal of the Academy of Marketing Science. 35(1), 127-143. DOI: 10.1007/s11747-0070015-7.

23. Wiedmann, K.P., \& Buxel, H. (2005). Corporate reputation management in Germany: results of an empirical study. Corporate Reputation Review. 8 (2), 145-163. DOI: 10.1057/palgrave.crr.1540246. 